Fakultas Hukum, Universitas Lampung, Bandar Lampung, Lampung, Indonesia. http://jurnal.fh.unila.ac.id/index.php/corruptio

Volume 2 Issue 2, July - December 2021. PP: 83-98

P-ISSN: 2723-2573 E-ISSN: 2745-9276

\title{
The Environment and Forestry Investigators' Authority in Money Laundering Offenses
}

\author{
Muh. Afdal Yanuar \\ Indonesia Financial Transaction Report and Analysis Center, Indonesia \\ yanuarafdal10@gmail.com
}

Submitted: Jun 15, 2021; Reviewed: Oct 23, 2021; Accepted: Oct 26, 2021

\begin{tabular}{l}
\hline Article's Information \\
keywords: \\
Authority; Legal Harmonization; and \\
Investigation.
\end{tabular}

\section{DOI :}

https://doi.org/10.25041/corruptio.v2i2.2348
Investigators from the Ministry of

Environment and Forestry (Kementerian

Lingkungan Hidup dan Kehutanan/ KLHK)

are not authorized to investigate the crime of money laundering in the elucidation of Article 74 of Law No. 8 of 2010, although they are authorized to investigate the crime of origin. However, the controversy over the interpretation of Article 74 of the Money Laundering Law was resolved by the Decision of the Constitutional Court Number 15/PUU$X I X / 2021$, which expands the meaning of 'predicate criminal investigator' in the provisions of Article 74 of the Money Laundering Law to become 'an official or agency authorized by legislation to carry out an investigation.' This paper attempts to describe the dynamics of the authority of KLHK investigators in investigating money laundering offences before and after the pronouncement of the Constitutional Court Decision Number 15/PUU-XIX/2021, including the matter of legal harmonization in the Money Laundering Law relating to the authority to investigate money laundering. This research is normative research with a conceptual approach, a statute approach, and a historical approach. Through this paper, this research can convey that before the Constitutional Court's Decision Number 15/PUU-XIX/2021, KLHK investigators were 
not authorized to investigate the crime of money laundering, and several legal disharmonies arose regarding the regulation of the authority to investigate money laundering. Meanwhile, after the Decision of the Constitutional Court Number 15/PUU$X I X / 2021$, all investigators authorized to investigate predicate crimes of money laundering offences, among other things, investigators of the Ministry of Environment and Forestry, are ex officio authorized to investigate money laundering offences. Furthermore, KLHK investigators are authorized to investigate money laundering offences against environmental and forestry crimes whose tempus delicti is before the pronouncement of the Constitutional Court Decision Number 15/PUU-XIX/2021.

\section{A. Introduction}

The existence of the crime of money laundering does not stand alone like other conventional criminal acts but is a crime that is related to other criminal acts (predicate offence), so it is appropriate to state that the crime is a condition sine qua non to predicate crimes as stated in Article 2 paragraph (1) of Law no. 8 of 2010 concerning the Prevention and Eradication of the Crime of Money Laundering. ${ }^{1}$ All countries, in general, support all aspects of anti-money laundering legislation. However, there are concerns about how that broad commitment is translated into concrete priorities. ${ }^{2}$ Ministry of Environment and Forestry Investigators or Kementerian Lingkungan Hidup dan Kehutanan (KLHK) hereinafter referred to as the 'KLHK Investigators' is investigator authorized to investigate the offenses in the forestry and environmental fields, based on Article 77 of Law No 41 of 1999 concerning Forestry (Forestry Law) $)^{3}$ and Article 94 paragraph (1) of Law 32 of 2009 concerning Environmental Protection and Management (hereinafter referred to as the Environmental Law) ${ }^{4}$. The forestry and environmental sectors criminal act causes are two of the predicate offenses of money laundering, as stipulated in Article 2 paragraph (1) letters w and x of Law No. 8 of 2010 concerning the Prevention and Eradication of Money Laundering (hereinafter referred to as the Anti-Money Laundering Law). KLHK investigators should also be authorized to investigate

\footnotetext{
1 Ajie Ramdan, "The Influence of Decision of The Constitutional Court No. 77 / PUU-XII / 2014 on The Eradication of Money Laudering - Comparing Indonesia to The Other Three Countries," Jurnal Penelitian Hukum De Jure 17, no. 3 (2017): 413-25.

${ }^{2}$ Nicholas Dorn and Michael Levi, "East Meets West in Anti-Money Laundering and Anti-Terrorist Finance: Policy Dialogue and Differentiation on Security, the Timber Trade and 'alternative' Banking," Asian Journal of Criminology 3, no. 1 (2008): 91-110, https://doi.org/10.1007/s11417-007-9041-0.

${ }^{3}$ Article 71 of Law Number 41 of 1999 concerning Forestry states: "In addition to Investigating Officers of the Indonesian National Police, certain Civil Servant Officers whose scope of duties and responsibilities include forest management, are given special authority as investigators as referred to in the Criminal Procedure Code."

${ }^{4}$ Article 94 paragraph (1) of Law Number 32 of 2009 concerning Environmental Management and Protection states: "In addition to investigators from the Indonesian National Police, certain civil servants within government agencies whose scope of duties and responsibilities are in the field of environmental protection and management are authorized as investigators as referred to in the Criminal Procedure Code to investigate environmental crimes.".
} 
money laundering offenses with predicate offenses in the forestry and environmental sectors. This is stipulated in the body of Article 74 of the Anti-Money Laundering Law, which states that "Investigations of money laundering offenses are carried out by investigators of predicate offenses following the provisions of the procedural law and statutory provisions unless otherwise stipulated by this Law".

However, later, the elucidation of Article 74 of the Anti-Money Laundering Law causes a legal bias if it is associated with a systematic interpretation with the body of Article 74 jo. Article 2 paragraph (1) of the Anti-Money Laundering Law. The legal bias is caused by the elucidation of Article 74 of the Anti-Money Laundering Law, limiting investigators of predicate offenses who are authorized to carry out investigations of predicate offenses. These investigators are Police investigators, Attorney General's Office, National Narcotics Agency or Badan Narkotika Nasional (BNN), Corruption Eradication Commission or Komisi Pemberantasan Korupsi (KPK), Tax Investigators, and Customs Investigators. In addition to the six institutions listed above, other institutions have the authority to investigate money laundering crimes, such as civil servant investigators from the Ministry of Maritime Affairs and Fisheries and civil servant investigators from the Ministry of Environment and Forestry ${ }^{5}$. As a result, not all "predicate crime investigators" are qualified to carry out Money Laundering investigations. This is the legislator's official interpretation, found in the explanation section of Article 74 of the Anti-Money Laundering Law.

In a situation where money laundering is in the environmental and forestry sector, KLHK is not authorized to investigate the offense of money laundering in the elucidation of Article 74 of the Anti-Money Laundering Law, even though they are authorized to investigate the predicate offense. Whereas empirically, based on data from the Ministry of Environment and Forestry, the number of criminal cases that have been handled can be ascertained that KLHK investigators have carried out money laundering activities, but no money laundering investigations are not minor. In this case, those whose predicate offense case files are complete (hereinafter referred to as the 'P-21'), but the money laundering cases have not been processed (in this case, an investigation step) from 2016-2019. There are around 567 cases. This is a consequence of elucidation of Article 74 of Anti-Money Laundering Law, not mentioning KLHK investigators as money laundering investigators. ${ }^{6}$

The legislators' basic norms that assets charged with money laundering are derived from criminal acts are similar in the three amendments to the money laundering law. This shared set of norms provides an understanding that there is no possibility of money laundering in the absence of a predicate crime. Money laundering is a separate crime based on the similarity of norms. ${ }^{7}$ The explanation above illustrates intersecting parts, which have consequences for the emergence of problems regarding legal certainty in law enforcement, especially on the problem of investigating money laundering offenses. Money laundering law enforcement is getting slower because the case must be handed over to other law enforcers who are authorized to conduct money laundering investigations or delegated to police investigators for separate

\footnotetext{
${ }^{5}$ Hendra, "Kewenangan Penyidik Pegawai Negeri Sipil Dalam Uang Yang Bersumber Dari Tindak Pidana Asal," Solusi 19, no. September (2021): 391-411, https://doi.org/10.1234/solusi.v19i3.431.

${ }^{6}$ Criminal cases are handled by KLHK investigators who are P-21, but money laundering cannot be investigated. There are around 567 cases. In these criminal cases, it can be ascertained that money laundering activities can also cause state loss. It is well known that the characteristics of environmental and forestry offenses are also very complex and very broad, involving many parties, being organized, multi-sectoral, and also related to other criminal acts. Vide Rasio of Ridho Sani's testimony at the trial of case No. 74/PUU-XVI/2018 dated 7 January 2019, as stated in the Constitutional Court's Decision No. 74/PUU-XVI/2018 p. 139.

${ }^{7}$ Yulianto and Bambang Waluyo, "Implikasi Hukum Tidak Diwajibkannya Pembuktian Tindak Pidana Asal (Tinjauan Pasal 69 UU No. 8 Tahun 2010 Dan Putusan Mahkamah Konstitusi Nomor 77-PUU-XII/2014)," De Lega Lata: Jurnal Ilmu Hukum 10, no. 2 (2020): 229-55, https://doi.org/10.30596\%2Fdelegalata.v6i1.4519.
} 
investigations (splitting). ${ }^{8}$ Legislators have long been preoccupied with the issue of criminally tainted money. Commonly thought to be the result of tax evasion, drug offenses, corruption, or, perhaps more concerning, terrorist activities. ${ }^{9}$ Forest crime is a worldwide and pervasive problem. Forest crimes jeopardize the sustainable management of forest resources worldwide. They also result in the loss of resources (particularly tax revenues) that should be in the government's treasury. ${ }^{10}$ Regarding legal certainty, Van Apeldoorn stated that legal certainty exists if what law applies to concrete problems can be determined. ${ }^{11}$ The elucidation of Article 74 of Anti-Money Laundering Law makes the legal choices that should be enforced biased. Whether it refers to the elucidation of Article 74 of the Anti-Money Laundering Law an sich, or it refers to the systematic interpretation between the body of Article 74 jo. Article 2 paragraph (1) of the Anti-Money Laundering Law.

In addition, another problem that also arises in the existence of the Article is discrimination against civil servant investigators. On one side, elucidation of Article 74 of Anti-Money Laundering Law gives Customs and Tax investigators (part of civil servants investigators) to investigate money laundering offenses. However, on the other side, other civil servants investigators, including KLHK investigators, who have the authority to investigate environmental and forestry offenses (which are two of the predicate offenses of money laundering), are not given the authority to investigate money laundering offenses. This is also contrary to the equality before the law principle, a fundamental State Law principle. ${ }^{12}$

A constitutional review has previously been carried out related to the elucidation of Article 74 of Anti-Money Laundering Law. The Constitutional Court has also decided it through Constitutional Court Decision No. 74/PUU-XVI/2018. In this decision, the Constitutional Court decided that the Petitioners' petition is unacceptable (Niet Onvankelijke Verklaard), which means that what is not fulfilled by the Petitioners is a matter of legal standing, or not on the content/substance of the object of the petition. ${ }^{13}$ Therefore, the Constitutional Court judges panel has not given legal considerations on the substance of the object of the petition. Therefore, it is possible to re-examine the constitutionality of the authority to investigate money laundering offenses by investigators of predicate offenses. This provision is not provided in the elucidation of Article 74 of Anti-Money Laundering Law, including KLHK investigators, to be authorized to investigate money laundering offenses.

Furthermore, on 25 March 2021, each 2 (two) Investigators from the Ministry of Environment and Forestry and the Ministry of Marine Affairs and Fisheries submitted a petition to the Constitutional Court regarding their investigative authority in money laundering offenses

\footnotetext{
${ }^{8}$ Prianter Jaya Hairi, "Putusan Mahkamah Konstitusi Terkait Kewenangan PPNS Dalam Penyidikan TPPU Dan Implikasinya Terhadap Penegakan Hukum," Negara Hukum 12, no. 2 (2021): 2, https://doi.org/10.22212/jnh.v12i2.2358.

${ }^{9}$ M M Gallant, "Money Laundering: An Endless Cycle? A Comparative Analysis of Anti-Money Laundering Policies in the United States of America, the United Kingdom, Australia and Canada," Journal of Banking Regulation 14, no. 2 (2013): 183-84, https://doi.org/10.1057/jbr.2012.21.

${ }^{10}$ Nalin Kishor and Arati Belle, "Does Improved Governance Contribute to Sustainable Forest Management?," Journal of Sustainable Forestry 19, no. 1-3 (2004): 55-79, https://doi.org/10.1300/J091v19n01_04.

11 Apart from this meaning, another meaning contained in legal certainty, according to Apeldoorn, is that legal certainty means legal protection. In this case, the disputing parties can be avoided from arbitrary judgment. This means the existence of legal certainty also limits the parties who have the authority related to a person's life, that is, judges and regulators. Furthermore, see: Peter Mahmud Marzuki, Penelitian Hukum (Edisi Revisi), Cetakan ke9, Jakarta: Kencana, 2014, p. 98 - 99.

12 According to A.V. Dicey, the concept of 'the rule of law' emphasizes three parameters: 1) supremacy of law; 2) equality before the law; 3) the constitution based on individual rights. Furthermore, see: Titik Triwulan Tutik, Pokok-pokok Hukum Tata Negara, Jakarta: Prestasi Pustaka Publisher, 2006, p. 61.

${ }^{13}$ Against a petitioner who does not have a legal standing, the Constitutional Court will decide that their petition cannot be accepted (niet ontvankelijke verklaard). Furthermore, see: Maruarar Siahaan, Hukum Acara Mahkamah Konstitusi Republik Indonesia, Jakarta: Sekretariat Jenderal dan Kepaniteran Mahkamah Konstitusi RI, 2006, p. $98-99$.
} 
investigation. ${ }^{14}$ As for the petition, the Constitutional Court decided through the Decision of the Constitutional Court Number 15/PUU-XIX/2021 that the Court granted all of the petitioner's petitions. And give an interpretation that "the meaning of 'predicate offenses investigators' are officials or agencies that are authorized by laws and regulations to carry out investigations." ${ }^{15}$ Thus, every investigator who is authorized to investigate predicate offenses of money laundering, ex officio, is also authorized to investigate allegations of money laundering.

Based on the explanations given in the background above, the formulation of the problem in this paper is as follows: First, how is the authority of the Ministry of Environment \& Forestry Investigators in investigating money laundering before the Constitutional Court decision Number 15/PUU-XIX/2021 and it's legal harmonization. Second, what are the legal consequences of the Constitutional Court's Decision Number 15/PUU-XIX/2021 on the authority of the Ministry of Environment and Forestry investigators in investigating the money laundering offences? and Third, what is the authority of the Ministry of Environment and Forestry Investigators in investigating money laundering offences which its tempus delicti was before the Constitutional Court Decision Number 15/PUU-XIX/2021?

This research is normative research with a conceptual approach, statute approach, and historical approach. This research refers to conceptual studies, applicable laws, regulations studies, and the history of the formation of laws studies (significantly the Articles that are the object of discussion in this paper). Besides that, this paper is based on secondary data as library data using the deductive reasoning method.

\section{B. Discussion}

\section{Authority of the Ministry of Environment \& Forestry Investigators in Investigating Money Laundering Before the Constitutional Court Decision Number 15/PUU- XIX/2021 and Its Legal Harmonization}

Authority can be defined as the authority, right, and power possessed to do something. Authority is a formal power, either from legislative power (given by law) or executive/administrative power. Authority is power over a particular group of people or power over an area of government. ${ }^{16}$ Authority is the formal power that granted by law. Then, within the authority there are powers (rechtsbe voegdheden). ${ }^{17}$ Juridically, the definition of authority is the ability given by legislation to cause legal consequences. ${ }^{18}$ According to H.D. Stoud, the definition of authority is a comprehensive set of rules governing the acquisition and exercise of government authority by public law subjects under public law. ${ }^{19}$ From the explanations above, it can be understood that one of the essential elements of authority is that there are rules that determine that authority. Regarding the authority of KLHK investigators, it is further regulated in Presidential Regulation Number 16 of 2015 concerning the Ministry of Environment and Forestry.

Based on Article 2 of Presidential Regulation Number 16 of 2015 concerning the Ministry of Environment and Forestry, it is stated that the Ministry of Environment and Forestry has the authority to carry out government affairs in the environment and forestry sector to assist the

\footnotetext{
${ }^{14}$ Vide point e, f, g, and h, of Petitioner's Legal Standing, on Constitutional Court Decision Number 15/PUUXIX/2021, p. $6-8$.

${ }^{15}$ Vide Dictum of the Constitutional Court Decision Number 15/PUU-XIX/2021, p. 55.

16 S. Prajudi Atmosudirdjo, Hukum Administrasi Negara (Ghalia Indonesia, 1981): 78.

17 Ateng Syafrudin, "Menuju Penyelenggaraan Pemerintahan Negara Yang Bersih Dan Bertanggung Jawab," Jurnal Pro Justisia IV, no. 1 (2000): 22.

18 Paulus Efendi Lotulung, Himpunan Makalah Asas-Asas Umum Pemerintahan Yang Baik (Bandung: Citra Aditya Bakti, 1994): 68.

19 Irfan Fachruddin, Pengawasan Peradilan Administrasi Terhadap Tindakan Pemerintah (Bandung: Alumni, 2004): 4.
} 
President in administering state government. Thus, the Ministry of Environment and Forestry (KLHK Investigators) investigators are most relevant to investigating forestry and environmental offenses. Provisions of KLHK as money laundering investigators is regulated in Article 77 paragraph (1) Forestry Law and Article 94 paragraph (1) Environmental Law.

Following KLHK as money laundering investigators, Article 36 letter b of Law Number 18 of 2013 concerning Forest Destruction stated that "For investigative purposes,.... investigator.... authorized: .... b. request assistance from the Financial Transaction Reports and Analysis Center to investigate the suspect's financial data”. KLHK investigators themselves are possible to investigate money laundering crimes whose offenses are in the KLHK authority (environmental and forestry offenses). The body of Article 74 of Anti-Money Laundering Law states that: "The investigation of money laundering offenses is carried out by investigators of predicate offenses following the provisions of the procedural law and statutory provisions unless otherwise stipulated by this Law." Meanwhile, based on Article 2 paragraph (1) letters w and $\mathrm{x}$ of Anti-Money Laundering Law, the environment and forestry offenses are two predicate money laundering offenses. The investigation of that predicate offenses is the object of the authority of the KLHK investigators.

The argument to elucidate Article 74 of Anti-Money Laundering Law predicates that investigators are authorized to investigate money laundering. The investigators mentioned in the elucidation of Article 74 of Anti-Money Laundering Law do not qualify KLHK investigators as investigators authorized to investigate money laundering. As for after the Constitutional Court Decision Number 15/PUU-XIX/2021, all investigators who are authorized to investigate predicate offenses of money laundering, inter alia, KLHK investigators, ex officio, are authorized to investigate money laundering. However, this is the reason why before Constitutional Court Decision Number 15/PUU-XIX/2021 was applied, KLHK investigators were not authorized to investigate money laundering offenses in the environmental sector.

Regarding the legal harmonization of Article 74 of Anti Money Laundering Law before the Constitutional Court's Decision Number 15/PUU-XIX/2021, it is essential to explain the meaning of 'legal harmonization.' Legal harmonization is an effort or process to realize harmony, conformity, compatibility, and balance between legal norms in legislation as a legal system within a unified framework of the national legal system. Thus the legal norms in the legislation as a sub-system within a unified framework of the national legal system are not hindered by differences, do not conflict with each other, and there is no duplication or overlap. ${ }^{20}$ Yuliandri explained that legal harmonization is also related to the implementation of legal synchronization during forming laws. Synchronization is directly related to determining the content of the law. Legal synchronization can be vertical and horizontal. ${ }^{21}$

Vertical harmonization can be defined as harmonizing lower laws and regulations with those higher up in the law and regulation hierarchy, where lower laws and regulations must not conflict with higher regulations. Horizontal harmonization necessitates the absence of conflict or overlap in the content of the same level of legislation that regulates the same thing or is related to each other in a single family of laws and regulations. The research will describe analysis related to legal harmonization after describing the idea concept as an analytical approach to 'money laundering investigators' legal harmonization in the environmental aspect.

\section{a. Definition of Predicate Offenses Investigators and Money Laundering Investigators Aspect}

In general, there are three main reasons why money laundering is combated and declared a criminal act. First, because it influences the financial system and the economy, it harms the

${ }^{20}$ Kusnu Goesnadhie, "Harmoni Hukum Dalam Perspektif Perundang-Undangan,” Jurnal Hukum 11, no. 27 (2004): 86.

21 Yuliandri, Asas-Asas Pembentukan Peraturan Perundang-Undangan Yang Baik: Gagasan Pembentukan Undang-Undang Berkelanjutan (Jakarta: Raja Grafindo Persada, 2013). 
world economy. Second, by making money laundering a crime, it will be easier for law enforcement officers to seize the proceeds of criminal acts, which can be difficult to seize in some cases, such as assets that are difficult to track or have been transferred to third parties. Third, by declaring the practice of money laundering as a criminal act and with the obligation to report suspicious financial transactions for financial service providers, this will make it easier for law enforcers to investigate money laundering criminal cases to the figures behind them. These figures are difficult to track down and arrest because, in general, they are not seen in the execution of a crime but enjoy a lot of the crime results. ${ }^{22}$ It is widely acknowledged that when investigating acquisitive crime, investigators must focus not only on obtaining evidence of the underlying crime's commission, but also on what happened to the criminal proceeds. ${ }^{23}$ Based on the provisions of Article 1 point 1 of the Criminal Procedure Code, it is explained that an investigator is a state police official of the Republic of Indonesia or a particular civil servant official who is given special authority by law to conduct an investigation. Based on Article 1 point 2 of the Criminal Procedure Code, it is explained that the investigation is a series of actions by the investigator according to the method regulated in this law to seek and collect evidence in making clear the criminal act that occurred and to find the suspect. So, in simple terms, investigators can be interpreted as Indonesian National Police Officers or certain civil servants who are authorized to seek and collect evidence. With that evidence, make clear the crime that occurred and find the suspect.

Money laundering is one of the most striking examples of criminal internal communications. In broad terms, we can say that the relationship of the money laundering problem with other crimes is worth considering in two ways: first, in terms of the connection of the laundering process with offenses that served as a source of income, and second, in terms of laundering offenses that are financed by laundered money. ${ }^{24}$ Money laundering itself is a follow-up crime, which means that to allow money laundering to occur, it is required that there must be a predicate offense. Predicate offense refers to all criminal acts, the core offenses of money laundering, follow-up crimes. ${ }^{25}$ Based on this explanation, the legal process of money laundering is not only carried out by investigating the money laundering offenses $a$ sich, but there must be an 'investigation of predicate offenses' and an 'investigation of money laundering itself. Because there is an investigative action, mutatis mutandis, an investigator must investigate the predicate offenses and the money laundering.

Based on the above understanding (that money laundering is a follow-up crime), 'predicate offense investigators' can be interpreted as investigators authorized to conduct investigations into each criminal act, a predicate offense of money laundering. ${ }^{26}$ Furthermore, concerning the investigation of money laundering, based on the body of Article 74 of the Anti-Money Laundering Law, it is stated that investigations of money laundering are carried out by investigators of predicate offenses following the provisions of the procedural law and statutory provisions unless otherwise stipulated by this Law.

\footnotetext{
${ }^{22}$ Anggara Dwi Putra, Hasnan Habib Sutikno, and Wahono Widodo, "Kewenangan Pejabat Pegawai Negeri Sipil (PPNS) Dalam Melakukan Penyidikan Terkait Tindak Pidana Pencucian Uang (Analisis Putusan MK Nomor 15/PUU-XIX/2021),"Ikamakum 1, no. 2 (2021): 377-95.

${ }^{23}$ R. E. Bell, “An Introductory Who's Who for Money Laundering Investigators," Journal of Money Laundering Control 5, no. 4 (2002): 287-95, https://doi.org/10.1108/eb027309.

24 Georgy Rusanov and Yury Pudovochkin, "Journal of Money Laundering Control," Journal of Money Laundering Control 5, no. 3 (2002): 192-243, https://doi.org/10.1108/eb027304.

${ }^{25}$ Supreme Court of the Republic of Indonesia, Naskah Akademis Money Laundering, Jakarta: MA RI, 2006, p. 58.

${ }^{26}$ Ferry Pranata, Hartiwiningsih, and Sulistiyanta, "Implementation of 'Follow the Money' Approach in Money Laundering Legal Instruments for Effective Asset Recovery in Corruption," International Law Journal 6, no. 3 (2020): 92-97, http://www.lawjournals.org/archives/2020/vol6/issue3/6-2-59.
} 
According to the above-mentioned systematic interpretation, the term "money laundering investigators" refers to investigators of the Indonesian National Police or certain civil servants. They are authorized to conduct investigations into money laundering predicate offenses. ${ }^{27}$ According to the elucidation of Article 74 of the Anti-Money Laundering Law, predicate offense investigators are officials from agencies authorized by law to conduct investigations. These regulated investigators are the Indonesian National Police, the Attorney General's Office, the Corruption Eradication Commission (KPK), the National Narcotics Agency (BNN), as well as the Directorate General of Taxes and the Directorate General of Customs and Excise, and Ministry of Finance of the Republic of Indonesia. The investigators qualified in the explanation of Article 74 of the Anti-Money Laundering Law do not qualify the KLHK investigators authorized to investigate the environment and forestry offenses, which are two of the predicate offenses of money laundering. This description shows that provisions regarding the definition of 'predicate offenses investigators' in Article 74 of Anti-Money Laundering Law have become a normatively paradoxical norm.

Furthermore, it will be unusual if the scope of the predicate offense investigator of money laundering as stated in the elucidation of Article 74 of the Anti-Money Laundering Law does not correspond to the scope of the predicate offenses of money laundering as stated in Article 2 paragraph (1) of the Anti-Money Laundering Law. This creates an illogical perception and legal uncertainty about who the parties are qualified to be 'predicate offenses investigators.'

Regarding legal uncertainty, it can be understood by first describing what is meant by legal uncertainty. Legal certainty is a question that can only be answered normatively, not sociologically. Legal certainty, normatively, is interpreted as a regulation that is made and promulgated with certainty because it regulates clearly and logically. Clearly is a norm without a doubt (multi-interpretation). While logically is that a norm has become a system of norms with other norms so that it does not clash or cause a conflict of norms. Norm conflicts arising from the uncertainty of rules can take the form of norm contestation, norm reduction, or norm distortion. ${ }^{28}$ In addition, according to Apeldoorn, that one of the meanings of legal certainty is that legal certainty means that it can be determined what law applies to concrete problems. ${ }^{29}$

From this explanation, it can be understood that if there are norms with multiple interpretations, there is a distortion (deviation) of the meaning of the norm. There is a bias in determining which legal provisions apply. Since then, there has also been legal uncertainty in the norm. Therefore, the 'money laundering investigator' is biased (multi-interpretation). The biased reason comes from a comparison between 'systematic interpretation of Article 1 point 1 of the Criminal Procedure Code is Article 74 (body) jo Article 2 paragraph (1) of Anti-Money

\footnotetext{
${ }^{27}$ In the Anti-Money Laundering Law's academic bill, one of the main concerns of law formation is the need for "Rearrangement of the Law on Money Laundering Examination Procedures." Furthermore, one sub-sections is the Granting of Authority to predicate offense investigators to investigate allegations of money laundering offenses (multi-investigators). In this subsection, it is explained that: “... problems begin to arise if the intelligence report from PPATK is found to indicate money laundering, while investigators of predicate offenses do not have the authority to investigate money laundering. If based on the alleged money laundering, the intelligence report of PPATK is then submitted to the Police for the investigation of the money laundering. At the same time, for the investigation of the predicate offenses investigated by investigators authorized to investigate the predicate offenses, then this is contrary to the 'handling cases in a simple, fast and low-cost way' principles".

Furthermore, see Academic Paper of the Anti-Money Laundering Law a quo, as in: Pusat Pelaporan \& Analisis Transaksi Keuangan, Memorie van Toelechting: Pembahasan Rancangan Undang-Undang Tentang Pencegahan dan Pemberantasan Tindak Pidana Pencucian Uang, Buku Satu, Jakarta: PPATK, 2011, p. 114 - 115.

28 Yance Arizona, “Apa Itu Kepastian Hukum?,” 2008, https://yancearizona.net/2008/04/13/apa-itu-kepastianhukum/.

${ }^{29}$ Apart from this meaning, another meaning contained in legal certainty, according to Apeldoorn, is that legal certainty means legal protection. In this case, the disputing parties can be avoided from arbitrary judgment. This means the existence of legal certainty also limits the parties who have the authority related to a person's life, that is, judges and regulators.
} 
Laundering Law' with an 'elucidation Article 74 of Anti-Money Laundering Law'. Thus it is mutatis mutandis because the meaning of 'money laundering Investigator' itself becomes legal uncertain. The existence of legal uncertainty is contrary to Article 28D paragraph (1) of the Indonesian constitution.

\section{b. Equal Positions Between the Ministry of Environment and Forestry Investigators with the Certain Civil Servant Investigators Who Have Become Money Laundering Investigators Aspect}

The principle of equality before the law in the Rule of Law principle is strengthened by the wetmatigheid van bestuur principle in the rechtsstaat, according to the explanation regarding the rule of law, which will be the primary analytical tool in the legal issues of this paper. It is clear that the clarification of Article 74 of the Anti-Money Laundering Law restricts who can be qualified as a money laundering investigator. Certain civil servant investigators are subjected to discriminatory treatment as a result of this limitation (KLHK Investigator is one of the civil servant investigators).

The elucidation of Article 74 of Anti-Money Laundering Law qualifies Tax Investigators and Customs Investigators as Money Laundering Investigators, where both investigators are civil servants investigators. However, other civil servants investigators who are also authorized to investigate predicate offenses of money laundering are not given the same authority to investigate money laundering. For example, empirically, the number of criminal cases that have been handled and it can be ascertained that KLHK investigators have carried out money laundering activities but no money laundering investigations are not small. In this case, those whose predicate offense case files are complete (hereinafter referred to as the 'P-21'), but the money laundering cases have not been processed (in this case, an investigation step) from 2016 -2019 , and there are around 567 cases. This is a consequence of elucidation of Article 74 of Anti-Money Laundering Law, not mentioning KLHK investigators as money laundering investigators. ${ }^{30}$

The Customs and Taxation Investigators were given the authority to investigate money laundering offenses. In contrast, the KLHK Investigator, a Civil Servant Investigator, is not given the authority to investigate money laundering offenses, even though environmental and forestry offenses are two of the predicate offenses of money laundering. This causes discriminatory treatment among civil servant investigators, contrary to the principle of equality before the law. The principle of equality before the law has been constitutionally contained in Article 27 paragraph (1) of the Indonesian Constitution, even though it is widely understood that money laundering is a follow-up crime. ${ }^{31}$ With this reflection, it is genuine and clear that there is a polemic or controversy in the law enforcement process over the 'predicate offense investigator' interpretation in the elucidation of Article 74 of Anti-Money Laundering Law. If the polemic, as mentioned earlier, continues, the principle of equality before the law has been violated. This means that it will be unequal if there is a predicate offense with an authorized investigator. Still, because the investigator is not mentioned in the elucidation of Article 74 of Anti-Money Laundering Law, the investigator is not authorized to investigate the money laundering case. It can be concluded that the disparity in treatment of tax and Customs investigators as civil servants investigators versus other civil servants investigators authorized

\footnotetext{
${ }^{30}$ Criminal cases are handled by KLHK investigators who are P-21, but money laundering cannot be investigated; there are around 567 cases. In these criminal cases, it can be ascertained that money laundering activities can also cause state loss. It is well known that the characteristics of environmental and forestry offenses are also very complex and very broad, involving many parties, being organized, multi-sectoral, and also related to other criminal acts. Vide Rasio of Ridho Sani's testimony at the trial of case No. 74/PUU-XVI/2018 dated 7 January 2019, as stated in the Constitutional Court's Decision No. 74/PUU-XVI/2018 p. 139.

${ }^{31}$ Muh. Afdal Yanuar, "Diskursus Antara Kedudukan Tindak Pidana Pencucian Uang Sebagai Independent Crime Dengan Sebagai Follow Up Crime Pasca Putusan Mahkamah Konstitusi Nomor 90/PUU-XIII/2015,” Jurnal Konstitusi 16, no. 4 (2019): 803.
} 
to investigate money laundering predicate offenses (including 'KLHK investigators') violates the equality before the law principle. Furthermore, because this principle is enshrined in Article 27 paragraph (1) of the Indonesian Constitution, this situation contradicts the wetmatigheid van bestuur principle. Which the two principles are the fundamental principles of state law.

\section{c. Correlation Between the Body and the Elucidation of Articles in the Regulation of the Authority for the Investigation of Money Laundering in Anti-Money Laundering Law Aspect}

As previously explained, the main problem related to the regulation of 'money laundering investigators' has sparked a discourse and controversy due to the elucidation of Article 74 of Anti-Money Laundering Law, which limits which predicate offenses investigators can investigate money laundering offenses. Meanwhile, in the body of Article 74 of the Anti-Money Laundering Law, it states that those authorized to investigate money laundering are investigators of predicate offenses. As for predicate offenses are contained in Article 2 paragraph (1) of Anti Money Laundering Law, which is environmental and forestry offenses among the expressive verb mentioned in the provision. These predicate offenses are objects of investigative authority from KLHK investigators, but they are not qualified as moneylaundering investigators in the elucidation of Article 74 of Anti-Money Laundering Law.

The preceding will appear incompatible if related to the guidelines and techniques for drafting laws and regulations. Within the framework of drafting laws and regulations, the Articles' elucidation must pay attention to (a) it does not conflict with the primary material regulated in the body, and (b) do not expand, narrow or add to the meaning of the existing norms in the body. ${ }^{32}$ As for Article 74 of Anti-Money Laundering Law's elucidation, it has contradicted the primary material in the body. It has also narrowed the understanding of norms in the body (vide body of Article 74 jo. Article 2 paragraph (1) Anti-Money Laundering Law). This should be based on the body of Article 74 Anti-Money Laundering Law, 'the money laundering investigator' is the investigator authorized to investigate the predicate offense of money laundering. However, the Article's elucidation gives contrary meanings that narrow the norms that exist in the body.

The descriptions above show that the Ministry of Environment and Forestry or Kajian Lingkungan Hidup dan Kehutanan (KLHK) investigators are not authorized to investigate money laundering whose predicate offenses are environmental and forestry offenses is a paradoxical matter. This is because Article 74 of Anti-Money Laundering Law's elucidation is the legal basis for the KLHK investigators. KLHK investigators are not authorized to investigate money laundering offenses. This regulation has not followed the guidelines and techniques for drafting laws and regulations regulated in Law Number 12 of 2011 concerning the Establishment of Legislation. So in terms of the formal form of the regulation, the elucidation of Article 74 of Anti-Money Laundering Law is an invalid norm. ${ }^{33}$

\footnotetext{
${ }^{32}$ Based on CHAPTER I: Systematics Section (Framework of Legislations), point 186 in Appendix II (Techniques for Drafting Legislation) of Law Number 12 of 2011 concerning the Establishment of Legislation, Articles elucidation must pay attention to the following: does not conflict with the primary material regulated in the body; does not expand, narrow, or add to the meaning of the existing norms in the body; not to repeat the primary material regulated in the body; does not repeat words' descriptions, terms, phrases, or meanings in the general provisions; and/or does not contain the delegation formula. Regarding the position of Appendix II, it is legally contained in Article 64 of Law Number 12 of 2011 concerning the Establishment of Legislation, which states that:

(1) The preparation of the Draft Legislation is carried out following the technique of preparing the legislation.

(2) Provisions regarding the technique of preparing the legislation as referred to in paragraph (1) are listed in Appendix II, which is an integral part of this law.

${ }^{33}$ Hans Kelsen stated that the law is valid if it is made by the institution or authority authorized to form it and is based on a higher norm so that in this case, a lower norm (lex inferior) can be formed by a higher norm.

Furthermore, see: Hans Kelsen, Teori Umum Tentang Hukum dan Negara (translated by Raisul Muttaqien), Bandung: Nusamedia \& Nuansa, 2006, p. 137 - 140. Meanwhile, according to Achmad Ruslan, regarding the formation of law, it must include: The authority to make laws; the content of the law; and mechanism of law
} 
By looking at the 3 (three) aspects described above, the main points of the above aspects are as follows:

1) The discrepancy between the elucidation of Article 74 of Anti-Money Laundering Law and Article 1 point 1 of the Criminal Procedure Code is the body of Article 74 jo Article 2 paragraph (1) of Anti-Money Laundering Law, shows the legal uncertainty regarding the definition of 'money laundering Investigator';

2) The investigators are authorized to investigate money laundering in the elucidation of Article 74 of Anti-Money Laundering Law. It does not qualify other civil servants investigators (including KLHK investigators) as 'money laundering investigators' shows discriminatory treatment among civil servant investigators authorized to investigate predicate offenses of money laundering. This shows that the elucidation of Article 74 of Anti-Money Laundering Law contradicts the equality before the law principle, which is the principle contained in Article 27 paragraph (1) of the Indonesian Constitution; and

3) The elucidation of Article 74 of Anti-Money Laundering Law, which contradicts and narrows the meaning of the norms in the body of Article 74 jo. Article 2 paragraph (1) of Anti-Money Laundering Law, shows that there is a discrepancy between the form of the elucidation of Article 74 of Anti-Money Laundering Law with the guidelines for the establishment of legislation as regulated in the Law Number 12 of 2011 concerning the Establishment of Legislation.

The points mentioned above show the existence of Article 74 of Anti-Money Laundering Law's elucidation before the Constitutional Court's Decision Number 15/PUU-XIX/2021. The article limited predicate offenses investigators authorized to investigate money laundering create a conflict/nonconformity with norms, either vertically, horizontally outward, or horizontally inward. The vertical conflict of norms is manifested in the explanation of point (b). The horizontally outward conflict of norms (inconsistency with provisions outside Anti-Money Laundering Law) can be seen in the explanation of point (c). As for the horizontally inward conflict of norms (inconsistency with the provisions in the Anti-Money Laundering Law) can be seen in the explanation of point (a).

The points above also clearly show that before the Constitutional Court's Decision Number 15/PUU-XIX/2021, there was disharmony in the provisions regarding which investigators are authorized to investigate money laundering crimes. Therefore, it has implications for bias regarding the authority of KLHK investigators to investigate money laundering, whose predicate offenses are environmental and forestry offenses. even though they are authorized to investigate environmental crimes and forestry crimes which incidentally are two of the TPA of TPPU

\section{Legal Consequences of the Decision of the Constitutional Court Number 15/PUU- XIX/2021 on the Authority of the Ministry of Environment and Forestry Investigators in Investigating Money Laundering}

A State Law requires the state to organize and strive for social welfare (bestuurzog) for its citizens. ${ }^{34}$ As a result, the State creates a plethora of regulations through its machinery in order to achieve this noble goal. However, legal norms are not in line with the development

formation. Furthermore, see: Achmad Ruslan, Teori dan panduan praktik pembentukan peraturan perundangundangan di Indonesia, Yogyakarta: Rangkang Education, 2013, p. 232 - 239.

Based on the point of view of Hans Kelsen and Achmad Ruslan above, the author constructs that the parameters of the validity of a legal norm are, if: Formed by an authorized institution or authority; The content of the material does not conflict with the higher provisions (lex posterior); and Formed based on procedures and guidelines for the formation of laws and regulations that have been determined.

${ }^{34}$ S. F Marbun, Dimensi-Dimensi Pemikiran Hukum Administrasi Negara. Yogyakarta (Yogyakarta: UII Perss, 2001). 
principles. At that point, a legal and political process is required to re-adjust the community's social needs in accordance with the applicable law. ${ }^{35}$ That legal policy will become the policy of a country, which will be implemented or implemented by that country. ${ }^{36}$

The Legal Policy above relates to the existence of a systematic, detailed, and basic strategy in formulating and establishing laws that have been and will be enacted. Legal policy hands over legislative authority to state administrators who are given the authority to do so, but by still paying attention to the values prevailing in society, all of which are directed solely in the context of achieving the aspired state goals. ${ }^{37}$ From this explanation, it can be understood that everything is directed solely to achieve the aspired state goals in a legal, political process.

The legal, political process itself can be realized through the legislative and judicial mechanisms. The legislative mechanism can be realized by forming a law that determines a legal policy direction from the formation of the law. Meanwhile, the judicial mechanism can be realized through a Constitutional Court Decision which determines the norm of the provision or revokes the validity of a provision.

By establishing Anti-Money Laundering Law a quo, the legislators want to transform the investigative authority from a single investigator to be a multi-investigator based on the authority to investigate predicate offenses. The ideals to be realized through Article 74 of AntiMoney Laundering Law have been contained in the Academic Paper on the Establishment of Anti-Money Laundering Law a quo. In the Academic Paper, it is explained that:

"...problems begin to arise if the intelligence report from PPATK is found to indicate money laundering, while investigators of predicate offenses do not have the authority to investigate money laundering. If based on the alleged money laundering, the intelligence report of PPATK is then submitted to the Police for the investigation of the money laundering. At the same time, for the investigation of the predicate offenses investigated by investigators authorized to investigate the predicate offenses, then this is contrary to the 'handling cases in a simple, fast and low-cost way' principles."

This explanation clearly illustrates the urgency of legal reform money laundering investigations because the legislators wanted every investigator authorized to investigate predicate offenses. Ex officio also authorized to investigate money laundering, o that the law enforcement process does not conflict with the handling cases in a simple, fast and low-cost way' principles, which is one of the general principles in the Criminal Procedure Code. Therefore, it is no exaggeration to say that the elucidation of Article 74 of Anti-Money Laundering Law limited and restricted the scope of money laundering investigators. Based on the list of investigators specified in the elucidation of Article 74 of Anti-Money Laundering Law, it is not in line with the legal spirit of forming the Anti-Money Laundering Law a quo.

As for the problems themselves, they initially reaped controversy and legal problems. However, after the Constitutional Court Decision Number 15/PUU-XIX/2021, the meaning of 'predicate offense investigator' in the elucidation of Article 74 of Anti-Money Laundering Law is expanded. This establishment became 'officials or agencies authorized by laws and regulations to carry out investigations,' causing the controversy and legal problems to be resolved. Through the decision of the Constitutional Court, all investigators who are authorized to investigate predicate offenses of money laundering, inter alia 'KLHK investigators', ex officio, is authorized to investigate the money laundering whose predicate offense investigation is under his authority.

\footnotetext{
${ }^{35}$ Satjipto Rahardjo defines legal policy as choosing and the methods to achieve specific social and legal goals in society. Furthermore, see: Satjipto Rahardjo, Ilmu Hukum, Bandung: Citra Aditya Bakti, 2000, p. 35.

${ }^{36}$ Moh. Mahfud MD, Membangun Politik Menegakkan Konstitusi (Jakarta: Rajawali Pers, 2010).

${ }^{37}$ Franz Magnis Suseno, Etika Politik:Prinsip-Prinsip Dasar Kenegaraan Modern (Jakarta: Gramedia Pustaka Utama, 1994).
} 


\section{Money Laundering Investigations Authority of the Ministry of Environment and Forestry Investigators Which Has a Tempus Delicti Before the Constitutional Court Decision Number 15/PUU-XIX/2021}

Concerning the authority to investigate money laundering, Article 74 of Anti-Money Laundering Law states that "Investigations of money laundering are carried out by predicate offenses investigators per the provisions of the procedural law and the provisions of laws and regulations unless otherwise stipulated under this law." As for the Elucidation of the Article, it is stated that:

"the meaning of 'predicate offense investigators' are officials from agencies authorized by law to carry out investigations, namely the Indonesian National Police, the Attorney General's Office, the Corruption Eradication Commission (KPK), the National Narcotics Agency (BNN), as well as the Directorate General of Taxes and the Directorate General of Customs and Excise, Ministry of Finance of the Republic of Indonesia.".

The meaning of the elucidation of Article 74 of Anti-Money Laundering Law has been expanded by the Constitutional Court through the Constitutional Court Decision Number 15/PUU-XIX/2021. In its dictum, the Court stated that "the meaning of 'predicate offense investigators' are officials or agencies that are authorized by laws and regulations to carry out investigations." Thus, after the Constitutional Court's Decision (since 29 June 2021), those authorized to investigate money laundering are investigators authorized to investigate predicate offenses of money laundering, including in this case 'KLHK investigators', if the predicate offenses are environmental and forestry crimes.

Regarding the issue of the authority to investigate money laundering offenses by KLHK investigators, which has a tempus delicti was before the Constitutional Court's Decision Number 15/PUU-XIX/2021, it is indeed an issue of its own that is interesting to discuss. Regarding this issue, precedent in jurisprudence can be used as a reference in correlation with the Constitutional Court Decision. The considerations regarding the authority of the Corruption Eradication Commission or Komisi Pemberantasan Korupsi (KPK) to investigate Money Laundering whose predicate offenses is corruption that occurred before the promulgation of Law No. 8 of 2010 (before 22 October 2010). ${ }^{38}$ This has been stated in the Constitutional Court Decision Number 77/PUU-XII/2014. In that Constitutional Court's Decision, the Court stated that "the KPK has the authority to investigate and prosecute money laundering, which has a tempus delicti before Law Number 8 of 2010, due to money laundering, offenses related to corruption offenses that handled by the KPK". In addition, this is also carried out to realize the 'justice which is simple, fast, and low cost' principle. ${ }^{39}$

In addition, a concrete case related to the authority of money laundering investigators to investigate money laundering offenses cases that occurred before the investigator was determined to be authorized to investigate money laundering can be found in the case of defendant M. Akil Mochtar. Referring to the M. Akil Mochtar case, there are 2 (two) judges legal considerations (ratio decidendi) related to this issue that are: ${ }^{40}$

1) The Panel of Judges concluded that KPK investigators were authorized to carry out the investigation. The KPK Public Prosecutor was authorized to prosecute money

\footnotetext{
38 The KPK, based on Article 11 of Law Number 30 of 2002 concerning Prevention and Eradication Corruption Commission, is only authorized to investigate Corruption offenses. Meanwhile, in Law Number 15 of 2002 jo Law Number 25 of 2003, the KPK is not an investigator authorized to investigate money laundering. The KPK was only authorized to investigate Money Laundering when Law Number 8/2010 (Anti-Money Laundering Law a quo) was enacted. The Elucidation of Article 74 of the Anti-Money Laundering Law states that the KPK is one of the predicate offenses investigators authorized to investigate Money Laundering.

${ }^{39}$ Vide the ratio decidendi of Constitutional Court Number 77/PUU-XII/2014, Point [3.19], p. 205.

${ }^{40}$ Vide the ratio decidendi of the Corruption Court Decision at the Central Jakarta District Court Number: 10/Pid.Sus/TPK/2014/PN.Jkt.Pst., p. 1060 - 1061.
} 
laundering committed by Defendant in the period before Law Number 8 of 2010 was enacted, using Law Number 15 of 2002 jo. Law Number 25 of 2003. Although it is only limited to the suspicion that the money laundering committed by Defendant was obtained from corruption offenses; and

2) According to the Panel of Judges, the prosecution can be carried out by the KPK Public Prosecutor because the meaning and nature of combining investigations between predicate offense and money laundering must be in line with the prosecution. Considering the essence and urgency of the combining, it is for smooth examination, which is based on the 'justice which is simple, fast, and low cost' principle.

Based on the Panel of Judges (ratio decidendi) consideration above, it can be concluded that related to the investigation of money laundering crimes by the KPK as stipulated in Article 74 of the Anti-Money Laundering Law. It is not intended only to investigate the crime of money laundering, which has a tempus delicti after the promulgation of Law Number 8 of 2010. However, the provisions of Article 74 of Anti-Money Laundering Law must be interpreted that the KPK has the authority to investigate money laundering since the enactment of Law Number 8 of 2010, whether the tempus delicti of the money laundering is before or after the enactment of Law Number 8 of 2010. This is because Article 74 of Anti-Money Laundering Law's provisions are based on an authority approach, not a tempus delicti approach. ${ }^{41}$

Based on this explanation, the KPK has the authority to investigate Money Laundering, which has a tempus delicti before the enactment of Law Number 8 of 2010. For the same reasons as stated in the Constitutional Court Decision Number 77/PUU-XII/2014, all investigators were authorized to investigate the money laundering after the Constitutional Court Decision Number 15/PUU-XIX/2021. Therefore, KLHK Investigators also have the authority to investigate money laundering, which has a tempus delicti before the Constitutional Court Decision Number 15/PUU-XIX/2021.

\section{Conclusion}

There are 3 (three) main problems regarding the legal harmonization of the authority to investigate money laundering in the Anti-Money Laundering Law, prior to the Constitutional Court Decision Number 15/PUU-XIX/2021. The explanations above clearly illustrate that the provisions regarding the authority to investigate money laundering in Anti-Money Laundering Law, before the Constitutional Court Decision Number 15/PUU-XIX/2021, resulted in a legal disharmony, which causes KLHK investigators are not authorized to investigate money laundering. The impact of implementing Constitutional Court Decision Number 15/PUUXIX/2021 expands the meaning of 'predicate offense investigator' with authority to investigate money laundering offense, in the elucidation of Article 74 of Anti-Money Laundering Law. Hence, since the Constitutional Court's decision, KLHK investigators have the authority to investigate money laundering, whose predicate offenses are environmental and forestry crime.

All investigators authorized to investigate money laundering after the Constitutional Court Decision No. 15/PUU-XIX/2021, inter alia, KLHK investigators, are authorized to investigate money laundering offenses with a tempus delicti that occurred before the Constitutional Court Decision Number 15/PUU-XIX/2021. This situation is similar to the Decision of the Constitutional Court Number 77/PUU-XII/2014 legitimizes the authority of the KPK to investigate money laundering, which has a tempus delicti before Law Number 8 of 2010 (which became the starting point for the KPK to have the authority to investigate money laundering crimes).

${ }^{41}$ Muh. Afdal Yanuar, Anotasi Putusan Perkara Tindak Pidana Pencucian Uang a.n. Terdakwa M. Akil Mochtar (PPATK, 2020), https://drive.google.com/file/d/19OV8xo_97WrbGosSjWcLXFM7rONx73x0/view?usp=sharing. 


\section{Bibliography}

\section{A. Books}

Atmosudirdjo, S. Prajudi. Hukum Administrasi Negara. Ghalia Indonesia, 1981.

Efendi Lotulung, Paulus. Himpunan Makalah Asas-Asas Umum Pemerintahan Yang Baik. Bandung: Citra Aditya Bakti, 1994.

Fachruddin, Irfan. Pengawasan Peradilan Administrasi Terhadap Tindakan Pemerintah. Bandung: Alumni, 2004.

Mahfud MD, Moh. Membangun Politik Menegakkan Konstitusi. Jakarta: Rajawali Pers, 2010.

Marbun, S. F. Dimensi-Dimensi Pemikiran Hukum Administrasi Negara. Yogyakarta. Yogyakarta: UII Perss, 2001.

Yuliandri. Asas-Asas Pembentukan Peraturan Perundang-Undangan Yang Baik: Gagasan Pembentukan Undang-Undang Berkelanjutan. Jakarta: Raja Grafindo Persada, 2013.

Suseno, Franz Magnis. Etika Politik:Prinsip-Prinsip Dasar Kenegaraan Modern. Jakarta: Gramedia Pustaka Utama, 1994.

\section{B. Journals}

Bell, R. E. “An Introductory Who's Who for Money Laundering Investigators." Journal of Money Laundering Control 5, no. 4 (2002): 287-95. https://doi.org/10.1108/eb027309.

Dorn, Nicholas, and Michael Levi. "East Meets West in Anti-Money Laundering and AntiTerrorist Finance: Policy Dialogue and Differentiation on Security, the Timber Trade and 'alternative' Banking." Asian Journal of Criminology 3, no. 1 (2008): 91-110. https://doi.org/10.1007/s11417-007-9041-0.

Gallant, M M. "Money Laundering: An Endless Cycle? A Comparative Analysis of AntiMoney Laundering Policies in the United States of America, the United Kingdom, Australia and Canada." Journal of Banking Regulation 14, no. 2 (2013): 183-84. https://doi.org/10.1057/jbr.2012.21.

Goesnadhie, Kusnu. "Harmoni Hukum Dalam Perspektif Perundang-Undangan." Jurnal Hukum 11, no. 27 (2004): 86.

Hairi, Prianter Jaya. "Putusan Mahkamah Konstitusi Terkait Kewenangan PPNS Dalam Penyidikan TPPU Dan Implikasinya Terhadap Penegakan Hukum.” Negara Hukum 12, no. 2 (2021): 2. https://doi.org/10.22212/jnh.v12i2.2358.

Hendra. "Kewenangan Penyidik Pegawai Negeri Sipil Dalam Uang Yang Bersumber Dari Tindak Pidana Asal." Solusi 19, no. September (2021): 391-411. https://doi.org/10.1234/solusi.v19i3.431.

Kishor, Nalin, and Arati Belle. "Does Improved Governance Contribute to Sustainable Forest Management?" Journal of Sustainable Forestry 19, no. 1-3 (2004): 55-79. https://doi.org/10.1300/J091v19n01_04.

Pranata, Ferry, Hartiwiningsih, and Sulistiyanta. "Implementation of 'Follow the Money' Approach in Money Laundering Legal Instruments for Effective Asset Recovery in Corruption." International Law Journal 6, no. 3 (2020): 92-97. http://www.lawjournals.org/archives/2020/vol6/issue3/6-2-59.

Putra, Anggara Dwi, Hasnan Habib Sutikno, and Wahono Widodo. "Kewenangan Pejabat Pegawai Negeri Sipil (PPNS) Dalam Melakukan Penyidikan Terkait Tindak Pidana Pencucian Uang (Analisis Putusan MK Nomor 15/PUU-XIX/2021).” Ikamakum 1, no. 2 (2021): 377-95.

Ramdan, Ajie. "The Influence of Decision of The Constitutional Court No. 77 / PUU-XII / 2014 
on The Eradication of Money Laudering - Comparing Indonesia to The Other Three Countries.” Jurnal Penelitian Hukum De Jure 17, no. 3 (2017): 413-25.

Rusanov, Georgy, and Yury Pudovochkin. "Journal of Money Laundering Control." Journal of Money Laundering Control 5, no. 3 (2002): 192-243. https://doi.org/10.1108/eb027304.

Syafrudin, Ateng. "Menuju Penyelenggaraan Pemerintahan Negara Yang Bersih Dan Bertanggung Jawab." Jurnal Pro Justisia IV, no. 1 (2000): 22.

Yanuar, Muh. Afdal. Anotasi Putusan Perkara Tindak Pidana Pencucian Uang a.n. Terdakwa M. Akil Mochtar. PPATK, 2020. https://drive.google.com/file/d/19OV8xo_97WrbGosSjWcLXFM7rONx73x0/view?usp= sharing.

_. "Diskursus Antara Kedudukan Tindak Pidana Pencucian Uang Sebagai Independent Crime Dengan Sebagai Follow Up Crime Pasca Putusan Mahkamah Konstitusi Nomor 90/PUU-XIII/2015.” Jurnal Konstitusi 16, no. 4 (2019): 803.

Yulianto, and Bambang Waluyo. "Implikasi Hukum Tidak Diwajibkannya Pembuktian Tindak Pidana Asal (Tinjauan Pasal 69 UU No. 8 Tahun 2010 Dan Putusan Mahkamah Konstitusi Nomor 77-PUU-XII/2014).” De Lega Lata: Jurnal Ilmu Hukum 10, no. 2 (2020): 229-55. https://doi.org/10.30596\%2Fdelegalata.v6i1.4519.

\section{Regulations}

Constitutional Court Decision Number 15/PUU-XIX/2021.

Law No 32 of 2009 concerning Environmental Protection and Management.

Law No. 41 of 1999 concerning Forestry.

Law No. 8 of 2010 concerning the Prevention and Eradication of the Crime of Money Laundering.

\section{Internet}

Arizona, Yance. “Apa Itu Kepastian Hukum?,” 2008. https://yancearizona.net/2008/04/13/apaitu-kepastian-hukum/. 